\title{
Ultrastructural and Surface Features of Apple Leaves following White Apple Leafhopper Feeding
}

\author{
Robert M. Welker ${ }^{1}$, Richard P. Marini' ${ }^{2}$, and Douglas G. Pfeiffer ${ }^{3}$ \\ Department of Horticulture, Virginia Polytechnic Institute and State University, \\ Blacksburg, VA 24061
}

Additional index words. Malus domestica, Typhlocyba pomaria, insect host $\times$ plant interaction, leaf injury

\begin{abstract}
White apple leafhopper (WALH; Typhlocyba pomaria McAtee) feeding damage on apple (Malus domestica Borkh.) leaves was examined with scanning and transmission electron microscopy. WALH created feeding holes in the (lower) abaxial epidermis, with no visible exterior evidence of cell injury to the adaxial (upper) epidermis. Feeding holes were located in areas of the leaf with high stomatal density and were near stomata. Groups of cells in the palisade layers were empty or contained coagulated cell contents. Adjacent, apparently noninjured, palisade cells contained an abundance of starch granules, possibly indicating that photoassimilate export was impaired. Spongy mesophyll cells abaxial to the feeding area were left intact as were the epidermal cells adaxial to the feeding area. External views of either epidermis and internal leaf views of injured cells indicated no cell wall collapse.
\end{abstract}

The white apple leafhopper (WALH) is an insect that feeds on the foliage of apple trees in North America. This pest has become more prevalent due to increased pesticide resistance and reduced predator and parasite populations because of current spray programs. Putnam (1941) studied the feeding mechanisms of the WALH and several other leafhoppers. His light microscopy work revealed that the WALH fed only in the palisade layers of apple leaves. He also reported that WALH did not remove entire cells from the leaf, but removed the cellular components of individually punctured cells, leaving the cell walls intact. Putnam (1941) noted this method of feeding did not cause a collapse of the leaf surface but created white stippling areas visible on the upper epidermis. No cells abaxial to the feeding area were feeding targets, and most spongy mesophyll cells were not injured.

The characteristic stippling injury due to WALH feeding apparently causes severe foliar injury, but the relationship between visible injury and leaf function, to our knowledge, has not been reported. In a previous experiment with WALH, considerable visible damage occurred before photosynthesis or transpiration were appreciably reduced (Marshall et al., 1942). Additionally, recent reports indicate that WALH may not be an important economic pest when populations are less than five nymphs per leaf (Beers et al., 1995; Welker et al., 1995). We used scanning and transmission

Received for publication 11 May 1995. Accepted for publication 2 Nov. 1995. The cost of publishing this paper was defrayed in part by the payment of page charges. Under postal regulations, this paper therefore must be hereby marked advertisement solely to indicate this fact.

${ }^{1}$ Graduate Assistant.

${ }^{2}$ Associate Professor, Horticulture

${ }^{3}$ Associate Professor, Entomology. electron microscopy (SEM and TEM, respectively) to examine the ultrastructural and surface features of apple leaves following WALH feeding.

\section{Materials and Methods}

In May 1990, 75 'Delicious'/MM.111 trees were planted in 12 -liter pots. The potting medium consisted of 1 peat : 1 perlite $(\mathrm{v} / \mathrm{v})$. Fertilizer was applied every 2 weeks as a 200 $\mathrm{mg} \mathrm{N} /$ liter solution of a $20 \mathrm{~N}-8.2 \mathrm{P}-15 \mathrm{~K}$ soluble fertilizer (Peters Fertilizer Products, W.R. Grace and Co., Allentown, Pa.). The trees were grown in an outdoor nursery area in Blacksburg, Va. On 25 Aug., field-collected, second-generation, first- or second-instar nymphs were placed on the trees to create populations of $0,0.5,1,2,4$, and 8 WALHs per leaf. There were five single-tree replications in a completely randomized design. In Sept. 1990, when winged adult WALHs had left the trees, 10 injured and five noninjured control leaves were selected for observation. The leaves were removed from the trees and immediately immersed in cold primary fixative of $4 \%$ paraformaldehyde : glutaraldehyde (v/v) and 0.1 M sodium cacodylate ( $\mathrm{pH} 7.0$ ) for $12 \mathrm{~h}$. Tissue samples for SEM and TEM consisted of 25- and 4- $\mathrm{mm}^{2}$ leaf sections, respectively. One SEM and TEM sample were removed from each leaf to provide five control and 10 WALH-injured samples for SEM and TEM. Samples were washed in $0.1 \mathrm{M}$ phosphate buffer ( $\mathrm{pH} 7.0$ ), postfixed in $2 \%$ osmium tetroxide ( $\mathrm{pH} 7.0)$, and were dehydrated in an alcohol series $(15 \%, 25 \%, 40 \%, 70 \%, 95 \%$, and $100 \%$ EtOH). SEM samples were criticalpoint dried, mounted on aluminum stubs, sputter-coated with $15 \mathrm{~nm}$ gold-palladium, and examined on a SEM (model 505; Phillips, Mahwah, N.J.) operated at $20 \mathrm{kV}$. TEM samples were fixed in an acetone series $(10 \%$, $20 \%, 50 \%, 80 \%$, and $100 \%$ resin), embedded in Spurr's resin, sectioned with a glass knife, and examined in a TEM (model 10C; Zeiss, Thornwood, N.Y.) operated at $80 \mathrm{kV}$.

In May 1991, four spur leaves infested with WALH nymphs were removed from each of three, 9-year-old 'Campbell Redchief Delicious'/MM.111 apple trees; the leaves had various amounts of visual WALH injury ranging from severe damage (about five WALH per leaf) to none. Because the leaves were collected mainly to view surface features with the SEM, internal cell integrity was not a major factor; thus, a faster more convenient fixation method was used. On removal from the tree, leaves were immediately immersed in liquid $\mathrm{N}$ for transport to the laboratory. Frozen leaves then were removed from the liquid $\mathrm{N}$ and gently were broken into smaller pieces. Leaf pieces were placed in paper cups filled with liquid $\mathrm{N}$ and were lyophilized for 3 days.

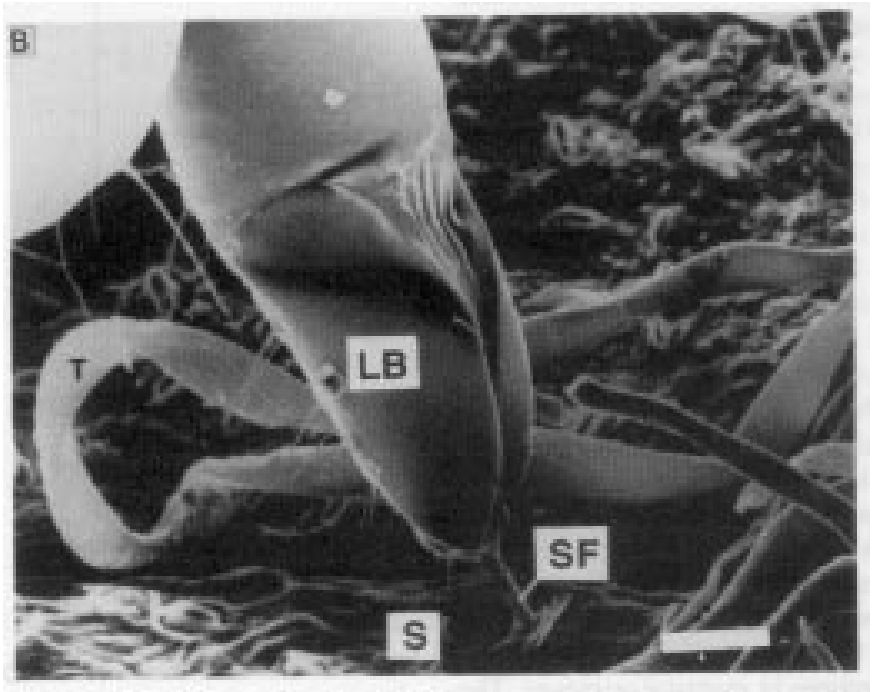

Fig. 1. The abaxial (lower) epidermis of a 'Delicious' apple leaf, with a white apple leafhopper nymph fixed while feeding on the leaf, shows the labium (LB) and stylet fascicle (SF) entering the leaf amid stomata (S) and trichomes (T). The light area in the upper left (B) is part of the insect leg. Scale bar $=50 \mu \mathrm{m}$. 


\section{Pest Management}

Samples then were mounted on aluminum stubs and sputter-coated with $30 \mathrm{~nm}$ of goldpalladium for examination in the SEM.

\section{Results and Discussion}

The adaxial (upper) epidermis of all of the leaves had an ordered arrangement of cells with few trichomes and no visible disruption from WALH feeding. The abaxial (lower) epidermis of all the leaves had an abundance of trichomes, which nearly occluded the epidermal cells from sight. Several intact WALH nymphs were found near major veins on the underside of the $\mathrm{N}$-fixed leaves. These observations agree with the reported feeding habits of WALH - they were found near veins, but the veins were not the feeding targets (Putman, 1941). Injured leaves had no major surface distortions, with the exception of puncture holes in the abaxial (lower) epidermis. Because some of the WALH nymphs were feeding at the time of fixation, it was possible to confirm the origin of the puncture wounds, as shown by the actual entry of the stylet fascicle into a leaf (Fig. 1). The size and shape of the hole are similar to those of other holes in the abaxial surfaces of all WALH-injured leaves. These holes in the leaf surface were considerably larger than those produced by other leaffeeding pests such as spider mites (Tetranychus urticae Koch.) (Campbell et al., 1990). A salivary flange may be seen surrounding the punctures. Neither flanges nor the salivary sheathes that usually accompany them are reported often from stippling "lacerate-andflush" leafhoppers (Backus 1985, 1988). However, Putman (1941) reported salivary sheathes formed by WALH, which projected as a layer surrounding the feeding puncture.

Most puncture wounds were located no more than one cell away from stomata (Fig. 2 $a$ and $b$ ) and in some cases nearly punctured the guard cells. The average distance between feeding holes and the nearest stomate was 22.4 $\mu \mathrm{m}$, while the average distance from that stomate to the four closest stomata was $56.7 \mu \mathrm{m}$. Because feeding holes seemed to be located near stomata, stomatal densities were determined near 15 randomly selected feeding holes. Stomata were counted within circular radii of $50,100,150$, and $200 \mu \mathrm{m}$ from the feeding holes. Regression analysis using the stepwise procedure of the Statistical Analysis System (SAS, 1985) was performed to determine the relationship between distance from the feeding puncture and stomatal density. Stomatal density was the response variable, and firstand second-order components of distance from the feeding hole were the regressor variables. The stomatal density decreased quadratically with increasing distance from the feeding hole (Fig. 3), which indicates that the insects select feeding sites in areas with high stomatal densities and tend not to puncture the leaf in areas void of stomata. This result agrees with Putman's (1941) observation of entry points near or sometimes in stomatal openings. The holes may be large enough to contribute to water vapor loss and alter leaf water relations. Because feeding holes were concentrated in
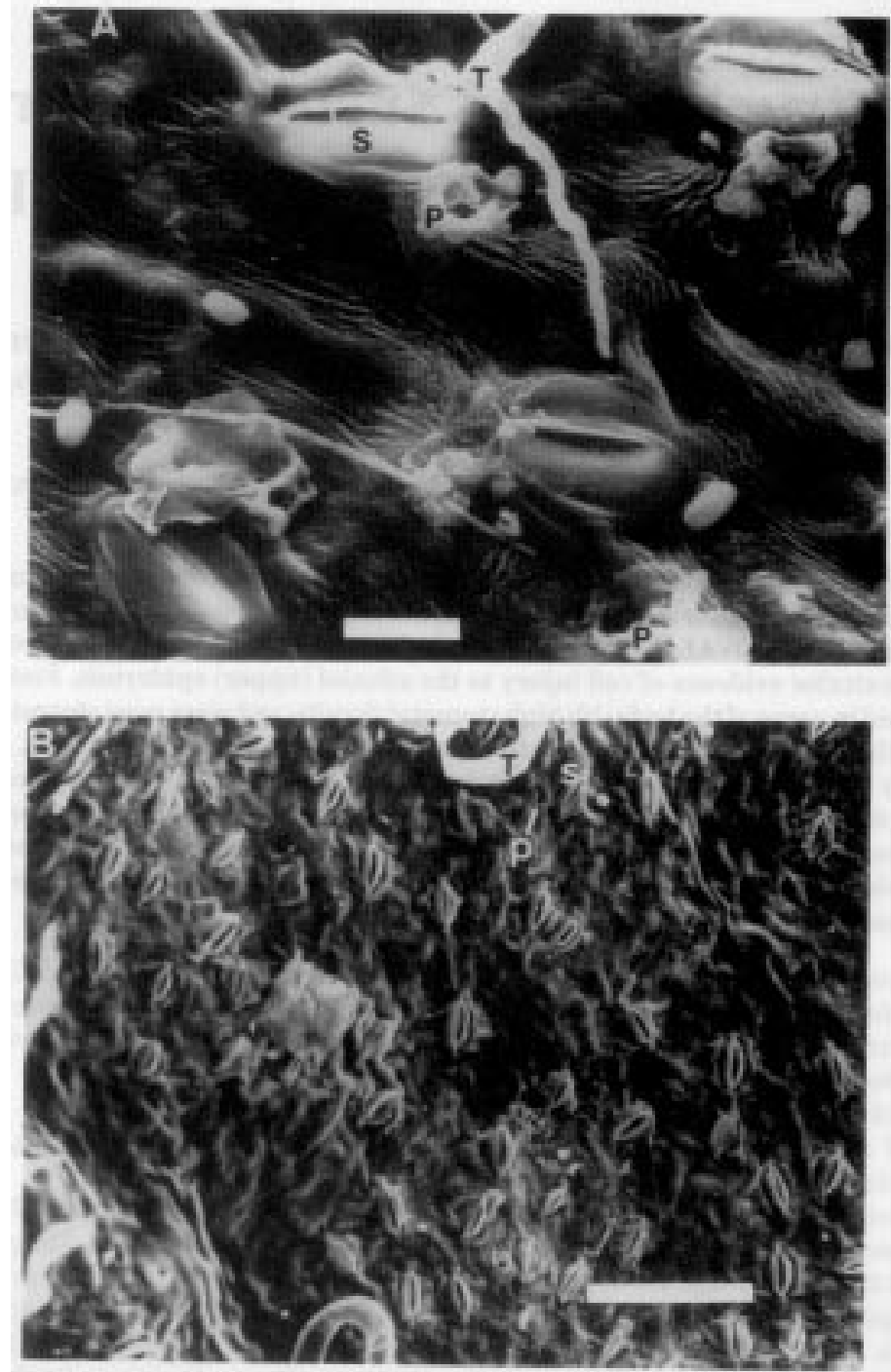

Fig. 2. (A and B) The abaxial (lower) epidermis of a 'Delicious' apple leaf showing trichomes (T), stomata (S), and the close proximity of the white apple leafhopper puncture wounds $(\mathrm{P})$. Scale bars $=(\mathbf{A}) 20 \mu \mathrm{m}$, (B) $0.5 \mathrm{~mm}$.

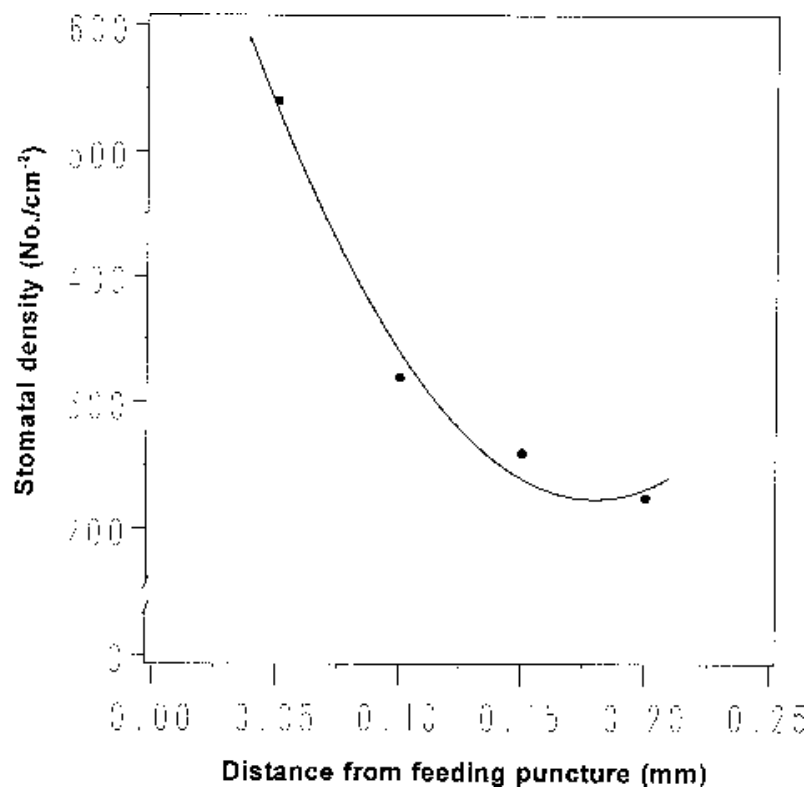

Fig. 3. Stomatal densities (SD) (stomata per square centimeter) at various distances from white apple leafhopper feeding punctures. Regression model: $\mathrm{SD}=821.53-6673.12$ distance +18787.5 distance $^{2}$, $\mathrm{n}=60, P \leq 0.0001, R^{2}=0.6167$. 


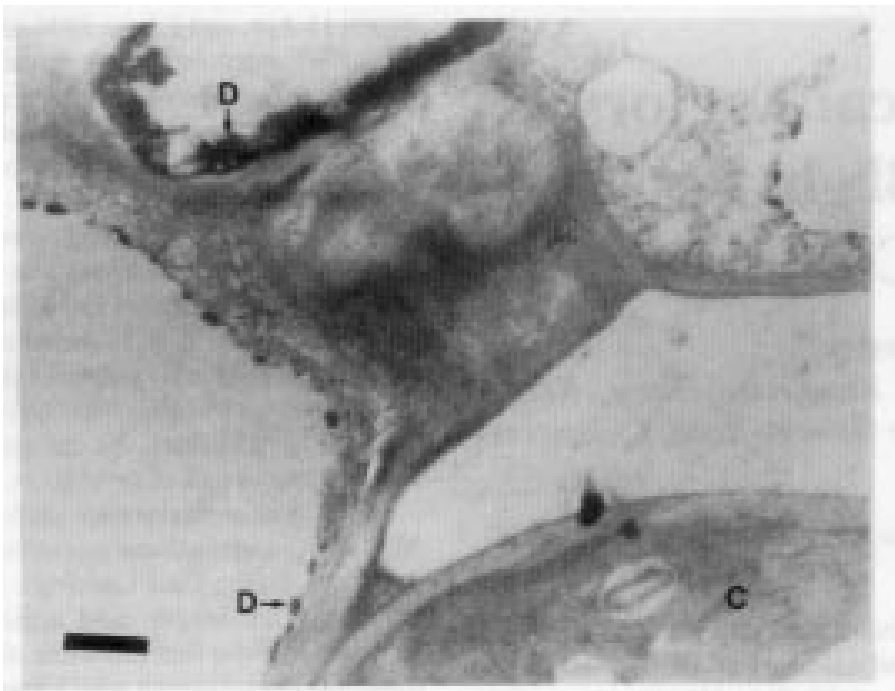

Fig. 4. Palisade cells of a 'Delicious' apple leaf showing a cell with a noninjured chloroplast (C) and injured cells nearby with electron-dense materials adhering to the walls (D). Scale bar $=1.0 \mu \mathrm{m}$.

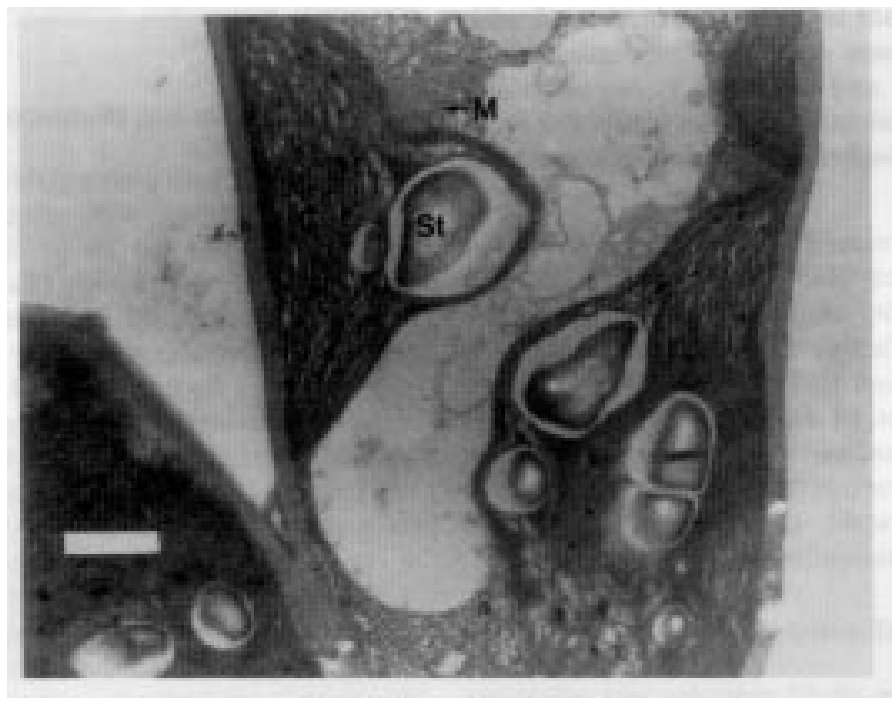

Fig. 5. A palisade cell of a 'Delicious' apple leaf showing chloroplasts (C), mitochondria (M), and the presence of starch granules $(\mathrm{St})$. Scale bar $=2.0 \mu \mathrm{m}$

areas with high stomatal densities, injured cells near the stomata may interfere with the ion balance between cells and may alter stomatal function. There were few puncture wounds relative to the amount of visual stippling damage apparent from the adaxial epidermis (data not presented), indicating that the insect feeds on a large area of the leaf per puncture. This finding supports other reports of large areas of visual stippling with few puncture wounds (Gunthardt and Wanner, 1981; Putman, 1941). The stippling on the adaxial leaf surface likely resulted from air entering empty cells of the palisade layer because there was no evidence of cell wall collapse.

There was no collapse or degradation of cell walls of internal cells, even when cell contents were absent. Vascular bundles and spongy mesophyll cells were not visibly damaged. Injured palisade cells were the only internal signs of WALH feeding found with
TEM. Large areas of palisade cells were completely devoid of contents or had small amounts of coagulated cell contents adhering to the cell walls. Within these areas of injured cells were isolated individual cells or groups of cells with no visible signs of direct WALH feeding damage (Fig. 4). Cells adjacent to completely empty cells contained all cellular components. This observation supports Putman's (1941) hypothesis that only cells directly punctured by the WALH maxillae are damaged and no internal breakdown of neighboring cells occurs. The only notable difference between noninjured cells in noninjured areas of the leaf and noninjured cells near the injured cells was the presence of many starch granules within the chloroplasts (Fig. 5). Only intact cells within WALH feeding areas contained these starch granules. Tanigoshi and Davis (1978) reported reduced photosynthate export from mite-damaged leaves, causing photosynthate accumulation in the leaves and starch granule deposition within the chloroplasts. Some cells within the feeding area were not damaged directly by WALH, but the surrounding damage likely isolated the cells enough to disrupt normal transport of photosynthates between cells. Putman (1941) found areas of noninjured cells within the feeding area of the WALH, but there was no indication that noninjured cells were affected adversely. Because we observed starch granules within the chloroplasts, we hypothesize that the rate of photosynthate export from the cell was reduced.

Although our objectives did not include determining the influence of WALH feeding on leaf physiology, 45 WALH-days (five WALH nymphs feeding on a leaf for 9 days) reduced net photosynthesis of spur leaves by $\approx 30 \%$ (Welker, 1992). Therefore, the level of feeding damage reported in this study does have a negative impact on leaf gas exchange rates. However, $>80$ WALH-days will likely be required to reduce crop value (Beers et al., 1995). We hypothesized that WALH feeding is of little economic importance because the first-generation nymphs feed on a small proportion of the total leaf area per tree and because the second-generation nymphs emerge late in the season when fruit development is nearly complete (Welker et al., 1995).

\section{Literature Cited}

Backus, E.A. 1985. Anatomical and sensory mechanisms of leafhopper and planthopper feeding behavior, p. 163-194. In: L.R. Nault and J.C. Rodriguez (eds.). The leafhoppers and planthoppers. Wiley, New York.

Backus, E.A. 1988. Sensory systems and behaviours which mediate hemipteran plant-feeding: A taxonomic overview. J. Insect Physiol. 34:151-165.

Beers, E.H., E.A. Elsner, and S.R. Drake. 1995. White apple leafhopper (Homoptera: Cicadellidae) effect on fruit size, quality, and return bloom of apple. J. Econ. Entomol. 88:973978.

Campbell, R.J., R.L. Grayson, and R.P. Marini. 1990. Surface and ultrastructural feeding injury to strawberry leaves by the twospotted spider mite. HortScience 25:948-951.

Gunthardt, M.S. and H. Wanner. 1981. The feeding behavior of two leafhoppers on Vicia faba. Ecol. Entomol. 6:17-22.

Marshall, G.E., N.F. Childers, and H.W. Brody. 1942. The effects of leafhopper feeding injury on apparent photosynthesis and transpiration of apple leaves. J. Agr. Res. 65:265-281.

Putman, W.L. 1941. The feeding habits of certain leafhoppers. Can. Entomol. 73:39-53.

SAS. 1985. SAS user's guide: Statistics. version 5 ed. SAS Institute, Cary, N.C.

Tanigoshi, L.K. and R.W. Davis. 1978. An ultrastructural study of Tetranychus mcdanieli feeding injury to the leaves of 'Red Delicious' apple (Acari: Tetranychidae). Intl. J. Acarology 4:47-56.

Welker, R.M. 1992. White apple leafhopper affects apple fruit quality and leaf gas exchange. MS Thesis, Virginia Polytechnic Institute and State Univ., Blacksburg.

Welker, R.M., R.P. Marini, and D.G. Pfeiffer. 1995 Leaf to fruit ratio, but not first-generation white apple leafhopper(Typhlocyba pomaria McAtee), influences apple fruit size and quality. J. Econ. Entomol. 88:959-964. 